\title{
"Culture” a Panacea for Brand Survival: Feasibility Analysis of Zimbabwe Tourism Destination
}

\author{
Farai Chigora (Corresponding author) \\ Faculty of Commerce, Catholic University of Zimbabwe, Zimbabwe \\ E-mail: fchigora@yahoo.com Tel: 263-772-886-871 \\ Promise Zvavahera \\ National University of Science and Technology, Zimbabwe \\ E-mail: promisezvavahera59@gmail.com Tel: 263-773-471-703
}

Received: July 31, 2015 Accepted: August 25, 2015 Published: November 9, 2015

doi:10.5296/bmh.v3i2.8545ＵRL: http://dx.doi.org/10.5296/bmh.v3i2.8545

\begin{abstract}
The study investigated culture as one the strategies that can be used to enhance survival of Zimbabwe tourism brand. This is because like other African tourism destinations, Zimbabwe is rich in unique traditional culture but failing to improve its global tourism brand identity. The study was based on a mixed methods research design combining both quantitative and qualitative approaches in collecting data from respondents. The qualitative method was used to find out the most crucial variables that contribute to culture identity in Zimbabwe tourism destination. This was done through in-depth interviews with the experts and managers in the tourism industry. The responses showed that the most common sources of culture identity are beliefs and norms, national dress code, galleries and heritage, originality in values and language. These variables were then investigated on their effect to Zimbabwe tourism destination branding using survey questionnaires as quantitative research instruments. The respondents for the questionnaires were from the travel sector, accommodation sector, resorts, Ministry of Tourism and Hospitality, Zimbabwe Tourism Authority, Ministry of Culture and Ministry of Environment. The results of the study show that national dress code is the most important source for Zimbabwe tourism cultural branding followed by galleries and heritages and originality in values. The study therefore recommended these three as the most core source for branding Zimbabwe tourism destination using culture. The other variables which are language, beliefs and norms have been regarded as supporting cultural factors and a model was designed to show the relationships.
\end{abstract}

Keywords: brand, culture, Zimbabwe, tourism destination, brand survival 


\section{Introduction}

Brands have been regarded as vital tools to enhance identity of organisations globally. They have been recognised as symbols, logos, taglines and other statements. The use of brands historically has been visible mainly in industries that deal with physical products as they are easy to label and identify due to their tangibility nature. The branding concept is increasingly becoming popular such that it is now practiced in tourism destinations. Destinations can be viewed in the form of a country, island or even towns (Hall, 2000). Tourism destinations are increasingly getting their identity and recognition in the form of brands. Globally tourism destinations have used brands to position themselves in the modern dynamic tourism markets. Zimbabwe tourism destination has not been left in this bandwagon as it is currently using the "World of Wonders" tourism brand. The current tourism brand for Zimbabwe tourism industry has come into existence after the failure of two main brands that have been used since the country's independence in 1980. Various strategies and campaigns have been employed by the country's tourism Destination Marketing Organisations (DMOs) spearheaded by expos and indabas with an objective to escalate the tourism brand. Branding has been done not only to the current Zimbabwe tourism brand but also to the previous ones that have failed to last on the world tourism market. This therefore, calls for a strong strategy to support the current Zimbabwe tourism brand. Culture has gained popularity as an identity component for a tourism destination. Poimiroo (2000) concurred by denoting that the history together with its associated culture and nature has become popular This has resulted in many destinations especially in Africa introducing a specified type of tourism known as "cultural tourism." Culture can be seen in the form of values, beliefs, norms and historical heritage enriched in tourism destinations. Success cases of various tourism industries are attributed to unique culture, nature and history that have been used to effectively project a positive image of a tourism destination (Ooi, 2001). This is a unique variable as it is different from one destination to another. It can be viewed from a tourism perspective providing uniqueness towards tapping unexploited in tourism development and informing a new segment for such types of tourism as cultural tourism and heritage tourism (Puczko \& Ratz, 2007). Tourism destinations can use culture as a variable that can strengthen branding and uniquely position on the world market. Zimbabwe tourism destination's brand survival can be extended through culture. Goeldner et al. (2000) denoted that it is not about better transport systems and hotels that make up a vibrant tourism destination, but aligning to traditional ways of living as they project a good image to tourists. The study explored the major cultural variables that are available in the Zimbabwe tourism destination and how they relate to Zimbabwe tourism brand so as to develop a model that uplifts the country's global position and identity.

\section{Problem Statement}

Culture has been recognised as a strong unique source of identity for tourism destinations. This emanates from the fact that the culture of people differs from one destination to another. The culture of Zimbabweans has been regarded as pure and unique but the tourism destination brand has continued to suffer a negative performance. The questions therefore arise on how to make the Zimbabwe tourism brand survive through culture. The study investigated the role of culture in uplifting the Zimbabwe tourism destination brand. 


\section{Literature Review}

The term culture can be viewed as a set of values, behaviours, wants and perceptions that have been learned and accepted by a part of society starting with a family to vital institutions (Kotler \& Armstrong, 1991). Culture as a resource does not only dwell on sights, galleries, events, performance and museums but includes the cultural identity symbolic value of destinations, residents' lifestyle and intangible cultural heritage (Urosevic, 2010). It can be regarded as a rich with diversity aspect which includes norms of a society, their language, architecture, art, traditions, dressing style, gastronomy, handicrafts, music and other issues (Triandis, 2002). Therefore cultural tourism is based on maintaining uniqueness on the international market relying on immensely valued natural heritages which have been preserved and other cultural resources (Urosevic, 2010). This works with destination branding as it is regarded in the form of symbols, marks or words that exist in order to give a destination its identity and differentiating it from others relaying a guarantee of memorable experience uniquely engulfed in a destination and recollection of enjoyable destination experience in one's memory (Goeldner et al., 2000). Culture can therefore be used to escalate such a destination branding standpoint at any given point in time. It is the basic connection of heritage and culture in tourism destinations that gives culture experience with uniqueness resulting in culture resource being an important image enhancement and improving quality of tourist destination (Urosevic, 2010).

\section{Methodology}

The research was based on a mixed methods research design. This was through applying both quantitative and qualitative approaches. Qualitative approach was used to establish the most common cultural variables that exist in the Zimbabwean tourism destination. This was through in-depth interviews with experts in the Ministry of Culture and Ministry of Tourism and Hospitality. The variables were further investigated on their effect to tourism through survey questionnaires as a quantitative approach. The population for the research was 90 respondents with 40 from the accommodation sector, 30 from travel sector, 25 from resorts, 5 from Ministry of Tourism and Hospitality, 5 from Zimbabwe Tourism Authority, 5 from Ministry of Environment and 10 from Ministry of Culture.

\section{Findings and Discussions}

The research carried a qualitative approach in order to determine the most dominant cultural variables making up the tourism destination. This was done with various experts and senior managers in the Ministry of Culture and Ministry of Tourism and Hospitality. The five identified variables were beliefs and norms, national dress code, originality in values, language, galleries and heritage. These were then assessed on their relation to the Zimbabwe tourism destination branding using a survey questionnaire and the results are as shown in table 1 below. 
Table 1. Average mean results of tourism destination brand relation to cultural variables

\begin{tabular}{|l|l|l|l|l|l|}
\hline Respondents & $\begin{array}{l}\text { Beliefs and } \\
\text { Norms }\end{array}$ & $\begin{array}{l}\text { National Dress } \\
\text { Code }\end{array}$ & $\begin{array}{l}\text { Originality in } \\
\text { Values }\end{array}$ & Language & $\begin{array}{l}\text { Galleries and } \\
\text { Heritage }\end{array}$ \\
\hline $\mathbf{1 . \quad \text { Travel Sectors }}$ & 2.561 & 2.119 & 2.622 & 3.871 & 2.810 \\
\hline $\begin{array}{l}\text { 2. Accommodation } \\
\text { Sector }\end{array}$ & 2.044 & 1.999 & 2.650 & 3.178 & 2.915 \\
\hline 3. Resorts & 2.356 & 1.845 & 2.918 & 3.167 & 1.011 \\
\hline $\begin{array}{l}\text { 4. Ministry of } \\
\text { Tourism and } \\
\text { Hospitality }\end{array}$ & 2.106 & 1.131 & 1.759 & 1.067 & 1.022 \\
\hline $\begin{array}{l}\text { 5. Zimbabwe } \\
\text { Tourism Authority }\end{array}$ & 1.015 & 1.215 & 1.785 & 2.166 & 1.825 \\
\hline $\begin{array}{l}\text { 6. Ministry of } \\
\text { Environment }\end{array}$ & 2.134 & 1.025 & 2.266 & 1.879 & 1.021 \\
\hline $\begin{array}{l}\text { 7. Ministry of } \\
\text { Culture }\end{array}$ & 1.012 & 1.056 & 1.345 & 1.745 & 1.067 \\
\hline Total Mean & $\mathbf{1 3 . 2 2 8}$ & $\mathbf{1 0 . 3 9 0}$ & $\mathbf{1 2 . 6 9 5}$ & $\mathbf{1 7 . 0 6 4}$ & $\mathbf{1 1 . 6 7 1}$ \\
\hline Average Mean & $\mathbf{1 . 8 9 0}$ & $\mathbf{1 . 4 8 4}$ & $\mathbf{1 . 8 1 4}$ & $\mathbf{2 . 4 3 8}$ & $\mathbf{1 . 6 6 7}$ \\
\hline
\end{tabular}

Note. The average mean are in a range of 1-5 (1= Strongly Agree; 5=Strongly Disagree).

Source: Research Survey (2015).

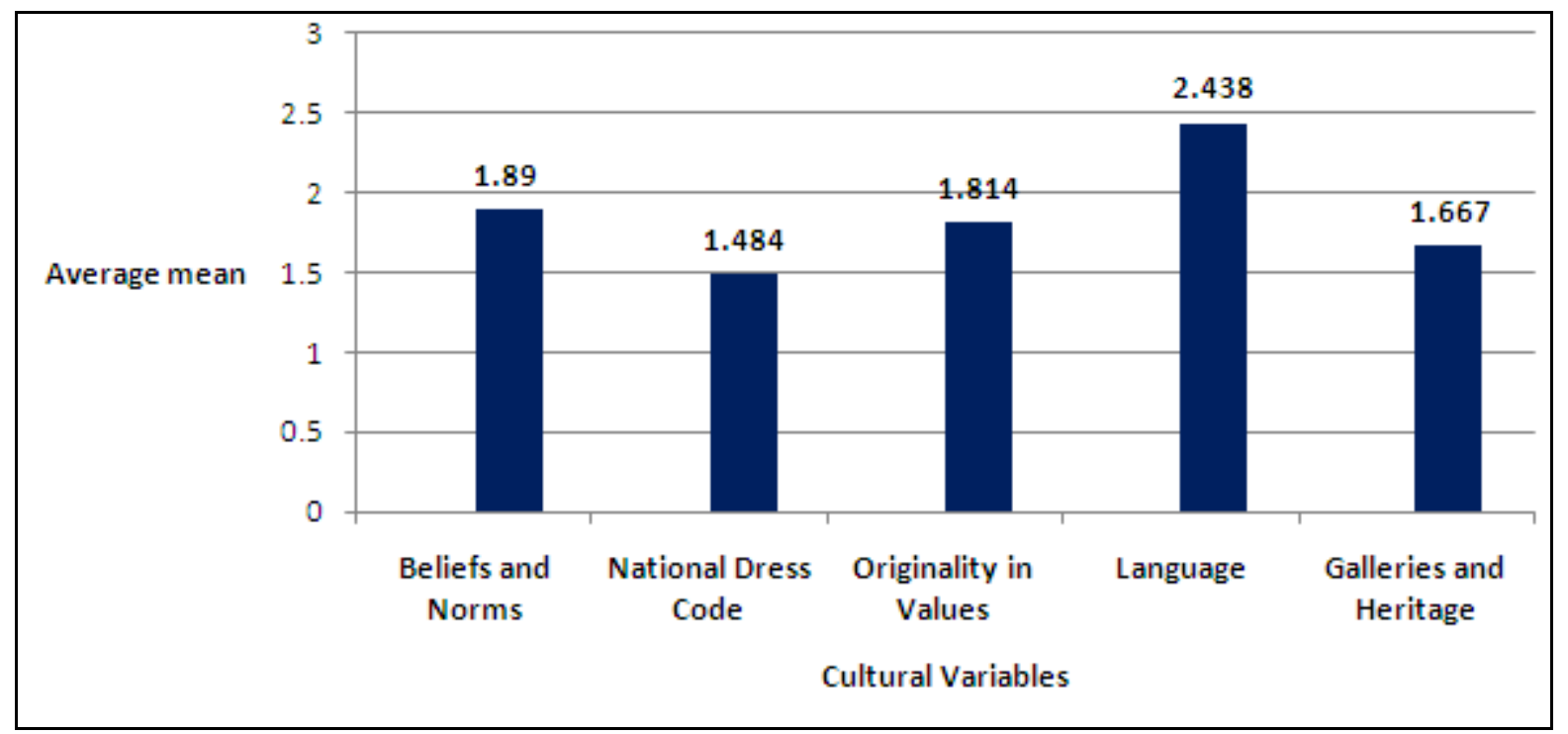

Figure 1. Average mean results on tourism destination brand relation to culture variables Note. The average mean are in a range of 1-5 (1= Strongly Agree; 5=Strongly Disagree). Source: Research Survey (2015). 
The average means presented in table 1 and figure 1 above shows that the respondents agreed that national dress code (1.484) is the most crucial cultural variable that can help in escalating Zimbabwe's tourism destination brand. Triandis (2002) also discovered dressing style amongst other variables as a critical cultural resource in a country. This is because dressing is more visible in our daily lives. The way we dress portrays where we come from to an extent that one can be identified anywhere in the world as of an African, Asian or European background from the way he or she dresses. This sums to an effect of identity enhancement such that dress code can be invited into the concept of destination branding and reposition Zimbabwe towards tourism glory.

Also galleries and heritage (1.667) have been pointed as prominent sources for branding Zimbabwe tourism destination through culture. This has been well supported by Urosevic (2010) demonstrating the most value symbolic elements of a cultural tourism. They help as sources of a destinations cultural history such that various tourists around the globe can just travel to see the protected cultural elements in galleries and heritage of the country. Zimbabwe as a tourism destination can take advantage of its unique culture residing in galleries and heritage centers.

Originality in values (1.814) has been discovered as another common variable for Zimbabwe tourism destination branding. The values of any tourism destination are tapped from the traditional customs dominating the history of a country. Values differ from one country to another. Maintaining originality of the values dominating a tourism destination may help the Zimbabwe tourism destination to reposition as prime country of visit.

\section{Recommendation}

There is need to have a national dress code as a move towards promoting cultural identity. Dressing is the immediate element that can be viewed by foreigners when they get into a destination. Tourists will therefore remember a destination when they take themselves with attires and pictures of Zimbabweans dressing code.

The country should put policies and structures that preserve natural heritage sustainably, having a future generation in mind. The natural heritage can be viewed in terms of buildings and ancient homes and other related variables. The tourists from developed world would want to see new different set ups not an imitation of their own style of living. They want a new experience that is unique from what they know. Imitating their buildings and way of leaving will remove originality and ability to lure more visitors.

Preservation of originality in museums, galleries and archives is also crucial as a strategy to promote and maintain local culture. This helps in reminding and educating the existing and coming generations on the importance of their culture. This can be turned to a branding catalyst as people will identify Zimbabwe tourism destination through its cultural richness. There is a sustainable cultural benefit that can be achieved by Zimbabwe as a tourism destination from these museums and galleries.

The study therefore recommended a cultural tourism destination branding model as shown in figure 2 below. 


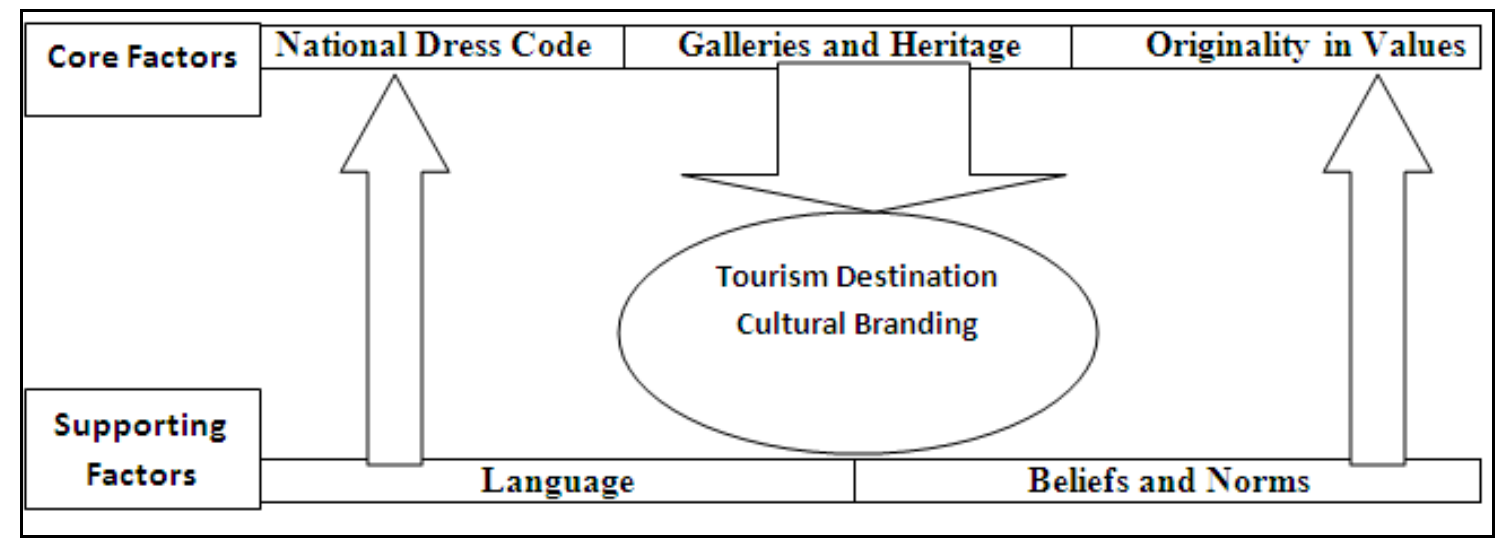

Figure 2. Cultural and tourism destination branding model

Source: Research Survey (2015).

\section{Conclusion}

Culture has been regarded as a unique element that is carried by a tourism destination. It is the values and beliefs of locals that cannot be imitated and helps in bringing identity. A tourism destination brand can therefore be identified and positioned through culture. However, Zimbabwe tourism destination is losing the branding benefits associated with culture enrichment. This is because of locals facing "identity crisis" as they are borrowing and copying cultures of visitors diluting their own strength. This can be seen from carnivals, individual and group visits in preserved areas that have resulted in acculturation. The majority of local Zimbabweans have followed dressing, language, music and expressions amongst other elements of foreign tourists leaving them lost in the wilderness of cultural brand identity.

\section{References}

Goeldner, C. R., Ritchie, J. R. B., \& MacIntosh, R. W. (2000). Tourism: Principles, Practices, Philosophies (8th ed.). New York: John Wiley \& Sons, Inc.

Hall, C. M. (2000). Tourism Planning: Policies, Processes and Re lationships. Harlow, UK: Prentice Hall, Inc.

Kotler, P., \& Armstrong, G. (1991). Principles of marketing (5th ed.). Englewood Cliffs, NJ: Prentice Hall, Inc.

Ooi, C.-S. (2001). Tourist Historical Products: Packaged Pasts of Denmark and Singapore. Scandinavian Journal of Hospitality and Tourism, 1(2), 113-132. http://dx.doi.org/10.1080/150222501317244038

Poimiroo, J. (2000). Cultural Tourism: No Joke. In C. R. Goeldner, J. R. B. Ritchie, \& McIntosh, R. W. (Eds.), Tourism: Principles, Practices, Philosophies (8th ed.). John Wiley \& Sons, Inc. 


\section{Macrothink}

Business and Management Horizons

ISSN 2326-0297

2015, Vol. 3, No. 2

Puczko, L., \& Ratz, T. (2007). Trailing Goethe, Humbert and Ulysses Tourism: Cultural Routes in Tourism. Cultural Tourism: Global and Local Perspectives. New York: Haworth Press

Triandis, H. C. (2002). Subjective culture. In W. J. Lonner, D. L. Dinnel, S. A. Hayes, \& D. N. Sattler (Eds.), Online Readings in Psychology and Culture (Unit 15, Chapter 1). Center for Cross-Cultural Research, Western Washington University, Bellingham, Washington USA. http://dx.doi.org/10.9707/2307-0919.1021

Urosevic, N. (2010). The effects of including the cultural sector in the tourist product of destination-strategic considerations regarding Istria as the region of cultural tourism and pula as the European capital of culture. Faculty of Tourism and Hospitality Management in Opatija. Biennial International Congress Tourism \& Hospitality Industry, pp. 1305-1317.

\section{Copyright Disclaimer}

Copyright for this article is retained by the author(s), with first publication rights granted to the journal.

This is an open-access article distributed under the terms and conditions of the Creative Commons Attribution license (http://creativecommons.org/licenses/by/3.0/). 